\title{
Organisational analysis of agricultural development cooperatives engaged in social support projects in rural areas for livestock production purposes
}

\author{
Emin Ertan GÖKHAN
}

Frrat University, Faculty of Veterinary Medicine, Department of Animal Health Economics and Management, 23119 Elazı $\breve{g}$, Turkey.

\begin{abstract}
Summary: The present study evaluates the extent to which the livestock production subsidies extended to Agricultural Development Cooperatives, whose members were, by means of Social Assistance and Solidarity Foundations, found to be in economic deprivation in rural areas, are implemented successfully in social and economic terms, and analyses the organisational structures of the cooperatives that benefit from the subsidies. The material of the study consists of the qualitative and quantitative data of eight agricultural development cooperatives with a total of 612 members that benefit from the livestock production subsidies under the Project for Social Support in Rural Areas (KASDEP) in the province of Elazı̆ . A SWOT analysis was conducted to identify the cooperatives' capability to survive under the current production and market conditions. 2.135.554,07 US\$ of a total subsidy amount of 3.876.851,75 US\$ extended to Elazığ Agricultural Development Subsidies between 2004 and 2007 was repaid according to the data for 2015 , which means a collection rate of $55.08 \%$, and the remaining $44.92 \%$ is expected to be repaid through debt restructuring. The number of families that benefit from the subsidies as members of the cooperatives and continue production is 142 , constituting $23.20 \%$ of the total number of members.
\end{abstract}

Keywords: Agricultural development cooperative, livestock production, rural poverty, rural support project, SWOT analysis

\section{Hayvansal üretim amacıyla kırsal alanda sosyal destek projesi yürüten tarımsal kalkınma kooperatiflerinin örgütsel analizi}

Özet: Bu çalışmada, üyeleri kırsal alanda ekonomik yoksunluk içinde oldukları Sosyal Yardımlaşma ve Dayanışma Vakıfları aracılığıyla belirlenen, Tarımsal Kalkınma Kooperatiflerine sağlanan hayvansal üretim desteklerinin uygulama başarılarının sosyal ve ekonomik açıdan ne düzeyde olduğu değerlendirilerek, destekleri kullanan kooperatiflerin örgütsel yapıları analiz edilmiştir. Çalışmanın materyali, Elazığ ilinde Kırsal Alanda Sosyal Destek Projesi (KASDEP) kapsamında hayvansal üretim desteği kullanan 612 üyeli sekiz Tarımsal kalkınma kooperatifinin nitel ve nicel verilerinden oluşmuştur. Kooperatiflerin mevcut üretim ve pazar koşullarında varlıklarını sürdürebilme yeteneklerini belirlemek amacıyla SWOT analizi yapılmıştır. Elde edilen verilere göre 20042007 yılları arasında Elazı ̆ Tarımsal Kalkınma kooperatiflerinin kullandığı toplam 5.798.801 TL desteğin (3.876.851,75 US\$) 3.194.255 TL'si (2.135.554,07 US\$) 2015 yıl sonu verilerine göre ödenmiş olup, geri dönüşüm \%55.08 oranında gerçekleşmekle birlikte geri kalan \%44.92'lik kısmın yeniden yapılandırılan alacaklarla geri dönüşümü beklenmektedir. Kooperatiflerin üyesi olarak desteklerden yararlanan ve üretime devam eden aile sayısı 142 olup, üye varlığının \%23.20'sini oluşturmaktadır.

Anahtar sözcükler: Hayvansal üretim, kırsal destek proje, kırsal yoksulluk, SWOT analizi, tarımsal kalkınma kooperatifi

\section{Introduction}

The social aspects and threatening widespread effects of poverty urge public authorities and nongovernmental organizations to address the fight against poverty as a primary objective. While its scope and content have undergone major changes, poverty reduction still remains to be the common problem of humanity (1). Countries implement programmes to fight poverty in rural areas with their policies and existing resources and attempt to ensure the development of the segments of their population that face the risk of poverty.
The main purpose of rural development strategies is to fight underdevelopment and ensure the agricultural, economic and social improvement of backward rural communities by helping them make more rational use of existing resources (24). Efforts have been made to close the social and economic gap between urban and rural areas by means of numerous models aimed at ensuring the development of rural areas, such as urban villages, central villages, rural area projects, and attractive village projects (6). 
One of the poverty reduction policies of Turkey is the project support. The Project for Social Support in Rural Areas (KASDEP) is intended to raise, through the most suitable organisations, the income of individuals and families living in economic and social deprivation in rural areas, to increase employment and to ensure that the livestock products produced are sold on-site, that the necessary material and technical support for marketing is provided in a timely manner, and that these people are involved in production on a continuous basis. The target group of the project is the citizens living in rural areas, who lack the resources necessary to be engaged in livestock production, wish to earn income from dairy farming and sheep breeding via cooperative organization and fall under the scope of the Law no. $3294(4,10)$.

With this project implemented in Turkey between 2003-2010, rural development cooperatives (with no less than 50 and no more than 120 members) whose members were, by means of Social Assistance and Solidarity Foundations (SYDV), found to be in economic deprivation were granted livestock farming subsidies. In line with these goals, a total of 322.544.630,23 US\$ was transferred to 74,062 families in a total of 994 projects under KASDEP in Turkey between 2003-2010 (19). While $29.52 \%$ of the population were living in rural areas of Turkey in 2007, this figure dropped to $22.72 \%$ in 2012. Although the total population increased by $7.14 \%$ between $2007-2012$, the rural population fell by $17.56 \%$ in the same period. While $27.99 \%$ of the population in the province of Elazı ğ were living in rural areas in 2007, it decreased to $25.54 \%$ in 2012 although the provincial population increased by $7.50 \%$ between $2007-2012$, the rural population in the province decreased by $5.13 \%$ (21).

Cooperatives operating in the field of dairy cattle, especially where competition is more intense nowadays, are more needed in rural areas (15). Cooperatives contribute to profitability increases through providing low-cost inputs relative to enterprises (14). Cooperatives, provide information on new production methods, effective organization and personnel management to producers (27), as well as they are also beneficial to producers in adopting and implementing effective production methods (16). Therefore, cooperatives support producers for a higher and more stable income (23).

To date, no studies have been found on the extent to which livestock production subsidies granted to the members of the Agricultural Development Cooperatives through SYDV have been assessed. Therefore, the aim of this study is to analyse the extent to which livestock production subsidies are given to members of the Agricultural Development Cooperatives through SYDV and the organizational structures of the beneficiary cooperatives.

\section{Materials and Methods}

The material of this study consists of the qualitative and quantitative data of eight rural development cooperatives with a total of 612 members that benefit from the income-generating livestock production project subsidies under the Project for Social Support in Rural Areas (KASDEP) in the province of Elazı ğ. The data were obtained through face-to-face interviews conducted with the officials of the Social Assistance Foundation and presidents of the cooperatives operating in the subprovinces of Baskil and Arıcak in Elazı $\breve{g}$ as well as with the president of the higher association to which the cooperatives were subordinate. In-depth interview technique, a qualitative research method, was employed in these interviews. The purpose of the research for the participants was explained and written informed consent was obtained from those who agreed to participate in the survey.

The cooperative presidents were asked what the procurement, production and marketing conditions they faced and the economic outputs they could obtain were, and a SWOT analysis was conducted in relation to the current status and future expectations of the cooperatives (5). This analysis helped to make an assessment of the internal aspects of the cooperatives and reveal their strong and weak aspects. Then, an external factors analysis was carried out to identify the position of the organizations relative to the rival companies as well as the opportunities and threats in the market.

\section{Results}

The below tables show the place of establishment, area of operation, scale of production of the cooperatives that borrowed livestock production loans under KASDEP in Elazığ as well as the breeds used in livestock production and the number of families that received subsidies (Table 1); details of the means of production acquired with the loans granted under KASDEP to the agricultural development cooperatives for livestock production purposes (Table 2); the year of allocation of the loans, loan amounts by years, amounts of the loans that have been repaid and the repayment percentages (Table 3); and the number of families that benefited from the loan subsidies and continue production within agricultural development cooperatives (Table 4).

The area of activity of the cooperatives is dairy farming. The total number of their members is 612 , and the initial scale of production is 1,224 head. Since members receiving project subsidies are required to have a stable with a capacity of 10 head, the total capacity of the enterprises registered in the agricultural development cooperatives in Elazı $\breve{g}$ is as high as 6,120 head and only $10 \%$ of this capacity can be used actively. 
Table 1. Place of the establishment, the area of activity, livestock assets, livestock breeds of the cooperatives under KASDEP in Elazı $\breve{g}$ and number of beneficiary families.

Tablo 1. Elazığ ili KASDEP kapsamında kooperatiflerin kuruluş yeri, faaliyet konusu, hayvan varlı̆̆ı, ırkı ve faydalanan aile sayısı.

\begin{tabular}{lccccc}
\hline \multicolumn{1}{c}{$\begin{array}{c}\text { Place of } \\
\text { establishment }\end{array}$} & Location & $\begin{array}{c}\text { Area of } \\
\text { activity }\end{array}$ & $\begin{array}{c}\text { Livestock } \\
\text { assets }\end{array}$ & Livestock breeds & $\begin{array}{c}\text { Number of } \\
\text { beneficiary families }\end{array}$ \\
\hline Harmantepe & Town & Dairy cattle & 200 & Brown Swiss & 100 \\
Tadım & Town & Dairy cattle & 200 & Brown Swiss & 100 \\
Kizıluşağ1 & Baskil District & Dairy cattle & 166 & Brown Swiss & 83 \\
Sarıkamış & Town & Dairy cattle & 200 & Brown Swiss & 100 \\
Arıcak & Arıcak District & Dairy cattle & 128 & Brown Swiss & 64 \\
Karaali & Baskil District & Dairy cattle & 108 & Simmental & 54 \\
Kavaktepe & Town & Dairy cattle & 110 & Holstein & 55 \\
Muratcık & Town & Dairy cattle & 112 & Simmental & 56 \\
Total & & & 1.224 & & 612 \\
\hline
\end{tabular}

Since the scope of activity of the cooperatives specified in Table 1 encompasses multiple villages, only the name of the residential area where their administration building is located is given in the tables.

Table 2. Means of production of the agricultural development cooperatives in Elazı $\breve{g}$.

Tablo 2. Elazığ ili tarımsal kalkınma kooperatiflerinin üretim imkânları.

\begin{tabular}{|c|c|c|c|c|c|}
\hline $\begin{array}{c}\text { Place of } \\
\text { establishment }\end{array}$ & $\begin{array}{l}\text { Cooperative } \\
\text { buildings } \\
\text { (pcs.) }\end{array}$ & $\begin{array}{l}\text { Enterprises } \\
\text { capacity } \\
\text { (head) }\end{array}$ & $\begin{array}{l}\text { Cooling } \\
\text { tank } \\
\text { (pcs.) }\end{array}$ & $\begin{array}{l}\text { Transportation } \\
\text { vehicles } \\
\text { (pcs.) }\end{array}$ & Dairies \\
\hline Harmantepe & 1 & 1.000 & 1 & 1 & 1 \\
\hline Tadım & 1 & 1.000 & 1 & - & 1 \\
\hline Kızıluşağ1 & 1 & 830 & 1 & 1 & - \\
\hline Sarıkamış & 1 & 1.000 & 1 & - & - \\
\hline Arıcak & 1 & 640 & 1 & - & - \\
\hline Karaali & 1 & 540 & 1 & - & - \\
\hline Kavaktepe & 1 & 550 & 1 & - & - \\
\hline Muratcık & 1 & 560 & 1 & - & - \\
\hline Total & 8 & 6.120 & 8 & 2 & 2 \\
\hline
\end{tabular}

Table 3. Amount of loans granted to the agricultural development cooperatives in Elazığ by years, amount of loans repaid, and repayment percentage.

Tablo 3. Elazığ ili tarımsal kalkınma kooperatiflerine yıllara göre aktarılan kredi miktarı, kredilerin geri ödenen miktarı ve geri dönüşüm oran1.

\begin{tabular}{lcrrr}
\hline Place of establishment & Year of loan allocation & $\begin{array}{c}\text { Year of loan allocation } \\
\text { (US\$) }\end{array}$ & $\begin{array}{c}\text { Amount of loan repaid } \\
\text { (US\$) }\end{array}$ & $\begin{array}{c}\text { Repayment percentage } \\
(\%)\end{array}$ \\
\hline Harmantepe & 2004 & $525.744,94$ & $291.675,75$ & 55.48 \\
Tadım & 2004 & $528.654,52$ & $187.865,62$ & 35.54 \\
Kızıluşağ1 & 2004 & $477.376,57$ & $421.902,72$ & 88.38 \\
Sarıkamış & 2005 & $585.360,52$ & $317.022,23$ & 54.16 \\
Arıcak & 2005 & $413.256,89$ & $404.625,10$ & 97.91 \\
Karaali & 2006 & $460.795,59$ & $278.188,87$ & 60.37 \\
Kavaktepe & 2007 & $389.951,53$ & $93.598,53$ & 24,00 \\
Muratcık & 2007 & $495.711,18$ & $140.675,25$ & 28.38 \\
Total & & $3.876 .851,75$ & $2.135 .554,07$ & 55.08 \\
\hline
\end{tabular}


Table 4. Number of families benefiting from loan subsidies and continuing production within the agricultural development cooperatives in Elazı̆g.

Tablo 4. Elazığ ili tarımsal kalkınma kooperatiflerinde kredi desteklerinden yararlanan ve üretime devam eden aile sayısı.

\begin{tabular}{lccc}
\hline \multicolumn{1}{c}{$\begin{array}{c}\text { Place of } \\
\text { establishment }\end{array}$} & $\begin{array}{c}\text { Number of beneficiaries } \\
\text { families under } \\
\text { KASDEP }\end{array}$ & $\begin{array}{c}\text { Number of families } \\
\text { continuing production under } \\
\text { KASDEP }\end{array}$ & $\begin{array}{c}\text { Percentage } \\
(\%)\end{array}$ \\
\hline Harmantepe & 100 & 20 & 20.00 \\
Tadım & 100 & 27 & 27.00 \\
Kizıluşağ 1 & 83 & 25 & 30.12 \\
Sarıkamış & 100 & 15 & 15.00 \\
Arıcak & 64 & 3 & 4.69 \\
Karaali & 54 & 14 & 25.93 \\
Kavaktepe & 55 & 15 & 27.27 \\
Muratcık & 56 & 23 & 41.07 \\
Total & 612 & 142 & 23.20 \\
\hline
\end{tabular}

Table 5. Assessment of the organizational factors internal and external to the agricultural development cooperatives in Elazığ. Tablo 5. Elazığ ili tarımsal kalkınma kooperatiflerinde örgütsel yapıların iç ve dış durum değerlendirmesi.

\begin{tabular}{ll}
\hline \multicolumn{1}{c}{ Internal factors } \\
\hline & \\
\hline & - Poor level of confidence among the members; \\
& - Strong urge to act individually; \\
& - Poor entrepreneurship qualities of the members; \\
& - Distributed residential areas of the members; \\
& - Reluctance of the members to attain the common goals; \\
& - Poor level of productivity of the livestock purchased on credit; \\
- Presence of the members willing to continue production & - Inadequate meadows and pasture lands; \\
despite the problems that have been experienced since the & - Inadequate care and feeding conditions due to high feed costs; \\
establishment of the cooperatives; & - Limited means of carrying out irrigated farming to cultivate \\
- Cooperative assets that may be utilized actively; & forage plants; \\
- Livestock production experiences of the members living in & - Poor leadership qualities that ensure the capability to engage \\
rural areas; & in common action; \\
- Rural labor potential. & - A strong perception among the members that the government \\
& will not take back the social benefits; \\
& - The inadequate economic potential of the members.
\end{tabular}

External factors

\begin{tabular}{ll}
\hline \multicolumn{2}{c}{ Opportunities } \\
\hline - Repayment conditions of loan subsidies allowing for no & Threats \\
repayment for two years and no interest for six years; & practice; \\
- Provision of administration building, stable and feed support & - Livestock deaths after procurement of livestock; \\
prior to commencement of production; & - Difficulties encountered in repayment of cooperative debts; \\
- Ease of access to town and city centers; & - Weakness in demand due to insufficiency of milk processing \\
- All cooperatives have milk cooling tanks; & facilities; \\
- Products can be sold at local markets; & - Delays and difficulties in insurance payments for livestock \\
- Increased demand for natural products produced by traditional & losses; \\
methods and perceived as specific to a region; & - Difficulties in procurement of feed due to seasonal drought; \\
- Socioeconomic relationship between urban and rural areas; & - Seasonal fluctuations in product prices; \\
- Repetition of the subsidy policies implemented in rural areas. & - Difficulties in being adapted to the market conditions. \\
\hline
\end{tabular}

The share of Elazığ's agricultural development cooperatives that have received livestock production loan subsidies under KASDEP in the total subsidies is $1.20 \%$. It was found that $55.08 \%$ of the loans granted to the cooperatives for dairy farming activities in Elazığ was repaid. The percentage of the families in the cooperatives that previously borrowed loans and currently continue production is $23.20 \%$, while the percentage of those that do not continue production is $76.80 \%$.

The findings of the evaluation of internal and external factors of cooperatives operating under KASDEP in Elazı̆̆ are given in Table 5. 


\section{Discussion and Conclusion}

Today, poverty has become a common problem in the entire world in parallel to globalization. Thus, poverty reduction strategies are included in the agenda of not only underdeveloped or developing countries but also developed ones (2).

Some of the studies conducted to explore the effects of agricultural investments on poverty found that agricultural investments had effects on reduction of poverty (11), that rural development subsidies granted to small producers and enterprises positively affected employment (8), that the growth in the agricultural sector had a higher effect on economic growth and poverty reduction compared to the industrial sector (13), and that the first step in breaking the poverty cycle was increasing agricultural productivity (20).

Being based on a cooperation model that combines and strengthens distributed and irregular means in rural areas, KASDEP aims to ensure that producers that were previously unable to sell their milk collectively in bulk amounts can sell their milk at higher prices to large enterprises under the umbrella of a cooperative, thereby earning regular income and using modern techniques in livestock farming (10).

Some of the comments expressed in some studies exploring the effects of social subsidies and microcredits granted to livestock farmers to reduce rural poverty in Turkey include that the projects have achieved the expected success $(9,12)$, that they have not succeeded in economic terms despite the social gains (7), and that they have not attained the expected goals in general $(17,25,1)$.

When the economic and social impact of producer organizations examined in the animal production, it is obviously seen that, collaboration and organization are the safer ways in terms of sustainability and profitability between producers (3). However, it decreases the risks faced by the cooperative members (26), along with an increase in the marketing, purchasing and bargaining power of small-scale enterprises (22). On the other hand, it was found that cooperative members marketed more milk than non-member enterprises while non-member enterprise administrators reported gaining lower income despite their higher entrepreneurial skills (18).

It was found that in the eight cooperatives established with 612 members under KASDEP, $76.80 \%$ of the members had withdrawn from production over time due to various reasons, most notably economic problems as well as reluctance of the members to attain the common goals, individual behaviour, low level of trust among members, and insufficiency of the members' entrepreneurial qualifications, whereas $23.20 \%$ of the members were found to be willing to continue production despite all the problems experienced so far. It was also found that $55.08 \%$ of the loans allocated to the cooperatives had been repaid and $45 \%$ was expected to be repaid through the continuous restructuring of the debts. The major reasons why the borrowers did not repay the loans include the failure of the cooperatives in the establishment, procurement, production, and marketing activities as well as the perception of the members that the government will not ask for repayment of the social benefits and the insufficiency of the members' economic power.

A study conducted in 16 dairy farming cooperatives established under KASDEP in Sanliurfa reports that all of the cooperatives terminated their operations and faced execution and attachment proceedings, and that all cooperative members make a living from state benefits and do not have the cash capital and minimum land required for the care of dairy cattle (17).

In a study exploring the economic and social effects of the subsidies granted for improvement of dairy farming to 14 cooperatives by the Ministry of Agriculture and Rural Affairs and to six cooperatives under KASDEP in Adana between 1990-2006, it is underlined that the number and productivity of the cattle distributed under the project were insufficient, that producers sold their milk at prices below the cost of production due to the high costs of feed, and that the project could not achieve the expected success due to the inefficiency of the cooperatives (25).

A study in which a dairy farming project carried out by a total of 21 cooperatives in Adana between 1990-2006 is assessed from the viewpoint of the cooperatives and their members reports that the project could not achieve the expected economic success due to the insufficiency of the number and productivity of the cattle distributed to the raisers, high costs of feed, sale of milk at a loss by the producers and inefficiency of the cooperatives (7).

In a study exploring the effectiveness of microcredits in Diyarbakir in 2005, it was found that the loans granted had been used to relieve the daily lives of people and get their previous business activities back on track, rather than creating new job opportunities (1).

In this study researching the activities of KASDEP in Elazığ between 2003-2010, carried out in an attempt to increase the level of income of people living in economic and social deprivation in rural areas, the results of the project were found to be unsuccessful.

While $23 \%$ of the families benefited from KASDEP and continue production, $77 \%$ terminated their operations. There are numerous internal and external factors that cause the failure of the cooperative organizations.

The merger under the umbrella of cooperatives did not arise from the demands of the members, but as a prerequisite to receiving the subsidies. Since the number of participants, which was required to be no less than 50 and no more than 100 members, was not sufficient, members from neighbouring villages were included, and no sufficient communication, coordination, trust and common goals could be established among them. Most of 
the members do not know the objectives, activities and legal obligations of the cooperatives, and have the perception that the subsidies granted from the social aid fund are social benefits and they will not have any obligation if they do not repay.

During the cooperatives' process of obtaining live material, serious problems were encountered in accessing sufficient supply of pregnant heifers of desired qualities. They had to settle for what they could obtain, rather than desired qualities. The support necessary for the care and feeding of the livestock could not be provided, and the necessary care and treatment activities could not be carried out due to the members' low level of income. Delays and difficulties were experienced receiving the insurance payments for livestock losses. Inadequate pasture lands and agricultural irrigation problems in the region were factors that restricted the capability to meet the forage needs of the livestock. Only two of the eight cooperatives attempted to carry out production and marketing activities, and the remaining cooperatives that could not survive in the market from the viewpoint of costs, prices, income, and competition terminated their functional activities although they legally continue to exist.

\section{References}

1. Adaman F, Bulut T (2007): Diyarbakır'dan İstanbul'a 500 Milyonluk Umut Hikayeleri Mikrokredi Maceralarl (Stories of Hope of 500 Liras: Microcredit Stories from Diyarbakir to Istanbul). İstanbul, İletişim Yayınları.

2. Akyıl N (2012): Kırsal Kalkınma Politikasının Yönetişimi. 75-81. In: 7. Bölgesel Kalkınma ve Yönetişim Sempozyumu Bildiri Kitabı. TEPAV Yayınları No:71, Ankara.

3. Andersson H, Larsen K, Lagerksvist CJ, et al. (2005). Farm cooperation to improve sustainability. Ambio, 34, 383-387.

4. Bıçkı D (2011): Rural Poverty in Turkey: The Case of Kocalar Village, Çanakkale. Uludağ J Econ Soc, 1, 161-180.

5. Cebecioğlu C (2006): SWOT analysis and application on a company. Graduate School of Social Science of Gebze Technical University, M. Sc. Thesis, Turkey.

6. Çakar YM (2007): The rural development application in the 1980 laters in Turkey and Çorum province examples. Graduate School of Social Science of Gazi University, M. Sc. Thesis, Turkey.

7. Çamoğlu SM, Yılmaz H, Aykut G, et al. (2012): The Analysis of Effects of Supports through Cooperatives to Livestock Farms on the Market Participation of Producers: Case of Adana Province. TJAE, 18, 13-22.

8. Dorward A, Fan S, Kydd J, et al. (2004): Institutions and economic policies for pro-poor agricultural growth. International Food Policy Research Institute, DSDG Discussion Paper, No:15.

9. Gül M, Yılmaz H, Akpınar MG, et al. (2013): Investigation of Economic and Social Effects of the Dairy Cattle Support Project to Regional Economy via Cooperatives: Example of Isparta Province. IJFSB, 7, 324329.

10. Güneş S (2009): Yoksullukla Mücadelede Mikro Kredi Uygulamaları ve Sosyal Yardımlaşma ve Dayanışma Genel
Müdürlüğü Proje Destekleri. Başbakanlık Sosyal Yardımlaşma ve Dayanışma Genel Müdürlüğü, Uzmanlık Tezi.

11. Irz X, Lin L, Thirtle C, et al. (2001): Agricultural productivity growth and poverty alleviation. Dev Policy Rev, 19, 449-466.

12. Koçturk OM (2009): A case study of increasing income of dairy cattle in rural area in western part of Turkey. $\mathrm{J}$ Anim Vet Adv, 8, 1685-1688.

13. Norton RD (2004): Agricultural development policy: Concepts and experiences. John Wiley \& Sons.

14. Ortmann GF, King RP (2007). Agricultural cooperatives I: History, theory and problems. Agrekon, 46, 18-46.

15. Quach TX, Kawaguichi T (2003). A Study on the Role and Development of Dairy Cooperatives in Honoi and Hochiminh City- A Case Study of Phudong and Taxuand Dairy Cooperatives. J Fac Agr Kyushu U, 48, 289-305.

16. Rotz CA, Zartman DL, Crandall KL (2005). Economic and environmental feasibility of a perennial cow dairy farm. JDS, 88, 3009-3019.

17. Sevinç G, Binici T (2016): General Situation of Breeding Cattle Cooperatives Founded With in The Context of Social Support Project at The Rural Area, The Problems and Solution Suggestions (Sanliurfa Sample). Harran J Agric F Sci, 20, 214-222.

18. Singh SRK, Chand R, Jha SK (2005). Impact assessment of milk cooperatives on dairying status of beneficiary farmers in Bihar. Indian J Anim Res, 39, 97-101.

19. SYGM (2015): Annual Report. Ministry of Family and Social Policies, General Directorate for Social Assistance, Turkey.

20. Timmer CP (1994): Population, poverty, and policies. The AER, 84, 261-265.

21. TSI (2016): The results of address based population registration system. Turkish Statistical Institute. Available at https://biruni.tuik.gov.tr/medas/?kn=95\&locale=tr (Accessed November 14, 2016).

22. Valentinov VL (2005). The organizational nature of agricultural cooperatives: a perspective from the farm problem theory. JRC, 33, 139-151.

23. Xinhua Z, Zhi T, Xueyan Y (2004). Study of information model of agricultural cooperative organization. J Zhejiang For Coll, 21, 442-445.

24. Yeșilbaş M (2011): Evolution Line of Rural Development Policies and Rural Development Approaches in the Planned Session. TID, 470, 153-176.

25. YIlmaz H (2010): Economic and social effects of support through cooperatives to dairy farms: Case of Adana province. Graduate School of Natural and Applied Sciences of Çukurova University, Ph.D. Thesis. Adana, Turkey.

26. Zeuli KA (1999). New Risk-Management Strategies for Agricultural Cooperatives. AJAE, 81, 1234-1239.

27. Zijun $\mathbf{Z}$ (2006). Chinese farmers' cooperation organization in the agricultural social service system. JIRCAS Working Report, 48, 67-74.

Geliş tarihi: 23.03.2018 / Kabul tarihi: 27.01.2019
Address for correspondence:
Asst. Prof. Dr. Emin Ertan GÖKHAN
Firat University, Faculty of Veterinary Medicine
Department of Animal Health Economics and Management
23119 Elazığ, Turkey
E-mail:eegokhan@firat.edu.tr 